\title{
PENGARUH JENJANG PENDIDIKAN, SKALA USAHA DAN LAMA USAHA TERHADAP PENGGUNAAN INFORMASI AKUNTANSI PADA UMKM DI KECAMATAN CIAWIGEBANG
}

\author{
Awanda Nirwana ${ }^{1}$ \\ Awandanirwana18@gmail.com \\ Dendi Purnama ${ }^{2}$ \\ dendi.purnama@uniku.ac.id \\ Program Studi Akuntansi Universitas Kuningan
}

\begin{abstract}
This research aims to analyze the effect of education levels, business scale and length of business on the use of accounting information. The population in this study were all MSMEs in Ciawigebang sub-district as many as 380 MSMEs. While the sample in this study were 79 MSMEs using the slopin formula and random probability with the provision of sample proportions. The data analysis technique used in this study is multiple regression analysis.Based on the results of the study indicate that the level of education, business scale, and duration of business have a significant positive effect on the use of accounting information. Thus, the level of education, business scale and duration of business are determinants of the use of accounting information on MSMEs.
\end{abstract}

Keywords: use of accounting information, education level, business scale, length of business

\section{PENDAHULUAN}

Usaha Mikro, Kecil, dan Menengah (UMKM) merupakan salah satu kegiatan ekonomi yang dilakukan oleh sebagian besar masyarakat di Indonesia (UU No 9 1998). Setiap perusahaan/badan usaha yang bergerak dalam Usaha Mikro, Kecil, dan Menengah (UMKM) mempunyai peran yang sangat penting bagi pertumbuhan ekonomi di Indonesia. Perusahaan/badan usaha yang bergerak dalam Usaha Mikro, Kecil dan Menengah (UMKM) tentunya berkeinginan untuk mengalami kemajuan dan perkembangan usaha.

\begin{abstract}
Keberhasilan usaha kecil dan menengah tidak terlepas dari kerja keras pemilik dalam mengelola usahanya serta kebijakan-kebijakan manajemen yang diterapkan pemilik usaha. Selain itu, keberhasilan perusahaaan tidak terlepas dari peran informasi akuntansi dalam mendukung aktivitas perusahaan.

Informasi akuntansi merupakan salah satu alat yang digunakan manajer untuk membantu menghadapi persaingan bisnis. Informasi akuntansi menghasilkan informasi yang relevan dan tepat waktu untuk perencanaan,
\end{abstract}


pengendalian, pembuatan keputusan dan evaluasi kinerja. Informasi akuntansi memungkinkan manajemen untuk mengimplementasikan strategi dan melakukan aktivitas operasional yang diperlukan untuk mencapai tujuan organisasi secara keseluruhan.

Industri kecil dan menengah banyak mengalami kesulitan dalam memahami penggunaan informasi akuntansi dengan baik. Padahal dengan semakin ketatnya persaingan bisnis dalam era globalisasi ekonomi, seharusnya mereka menggunakan informasi akuntansi sebagai kebutuhan dalam menjalankan bisnisnya. Penerapan Informasi akuntansi dalam pengelolaan keuangan usaha mikro kecil dan menengah (UMKM) dinilai masih kurang dipahami oleh para pelaku UMKM. Hal ini dikarenakan masih banyak pengusaha kecil yang belum melakukan pencatatan akuntansi dengan baik. Para pengusaha kecil dan menengah biasanya hanya melakukan pencatatan pembukuan tradisional yaitu sebatas pencatatan penjualan atau pendapatan saja. Akibatnya, laba bersih sulit untuk diketahui sehingga pengajuan kredit ke bank untuk modal usaha sulit diperoleh, dikarenakan sebagian besar dari pelaku UMKM memiliki keterbatasan-keterbatasan untuk menghasilkan laporan keuangan yang berkualitas (Kementerian Koperasi dan UMKM, 2014). Kondisi seperti ini terjadi pada UMKM di kecamatan Ciawigebang dalam hal penggunaan informasi akuntansi masih belum banyak yang memahaminya ditambah dengan pernyataan oleh salah satu manajer UMKM di Kecamatan Ciawigebang yang menyatakan bahwa para pengusaha kecil tidak memiliki pengetahuan akuntansi dan banyak diantara mereka yang belum memahami pentingmya pencatatan pembukuan sehingga laporan keuangan yang disusun oleh pelaku UMKM tersebut hanya sebatas untuk melihat keuntungan semata dan bukan untuk sebagai mengevaluasi hasil pencapaian usahanya.

Berikut ini adalah data penggolongan UMKM Kecamatan Ciawigebang yang menggunakan informasi akuntansi dan yang tidak menggunakan informasi akuntansi :

Tabel 1

Data UMKM Kecamatan Ciawi

\begin{tabular}{|c|c|c|c|c|}
\hline No & UMKM & $\begin{array}{c}\text { Jumlah } \\
\text { siswa }\end{array}$ & $\begin{array}{c}\text { Menggunakan } \\
\text { informasi akuntansi }\end{array}$ & $\begin{array}{c}\text { Tidak Menggunakan } \\
\text { informasi akuntansi }\end{array}$ \\
\hline 1. & Menengah & 98 & 70 & 20 \\
\hline 2. & Kecil & 117 & 23 & 94 \\
\hline 3. & Mikro & 165 & 13 & 152 \\
\hline \multicolumn{2}{|c|}{ Jumlah } & 380 & 106 & 266 \\
\hline
\end{tabular}

Berdasarkan data diatas dapat dilihat bahwa dari 380 UMKM yang ada di Kecamatan Ciawigebang sebanyak 266 UMKM belum menggunakan informasi akuntansi secara
Optimal sehingga menjadi kendala UMKM dalam meningkatkan operasionalnya karena sebagian besar masih menggunakan informasi tradisional. Oleh Karena itu, berbagai kendala yang dihadapi 
pelaku UMKM dimulai dari latar belakang pendidikan yang tidak mengenal mengenai akuntansi atau tata buku, kurang disiplin dan rajinnya dalam pelaksanaan pembukuan akuntansi, hingga tidak adanya kecukupan dana untuk mempekerjakan akuntan atau membeli software akuntansi untuk mempermudah pelaksanaan pembukuan akuntansi. Menurut Wulandari (2016) terdapat beberapa faktor yang dapat mempengaruhi penggunaan informasi akuntansi seperti jenjang pendidikan, skala usaha dan lama usaha dan pengetahuan akuntansi. Penelitian ini mereplikasi penelitian yang telah dilakukan Wulandari (2016). Perbedaan penelitian ini terletak pada objek penelitian yang dilakukan di wilayah kecamatan Ciawigebang Kabupaten Kuningan.

Jenjang pendidikan adalah tahapan dasar yang ditetapkan berdasarkan tingkat perkembangan peserta didik, tujuan yang akan dicapai dan kemampuan yang dikembangkan (UU No. 20, 2003). Tingkat pendidikan adalah tahapan pendidikan yang ditetapkan berdasarkan tingkat perkembangan peserta didik, tujuan yang akan dicapai dan kemauan yang dikembangkan. Tingkat pendidikan yang lebih tinggi akan lebih banyak memperoleh informasi dan mengimplementasikannya dalam perilaku dan gaya hidup sehari-hari. Sehingga dengan jenjang pendidikan yang tinggi akan lebih mudah memahami tentang penggunaan informasi akuntansi.

Skala usaha merupakan kemampuan perusahaan dalam mengelola usahanya dengan melihat berapa jumlah karyawan yang dipekerjakan dan berapa besar pendapatan yang diperoleh perusahaan dalam satu periode akuntansi (Nicholls dan Holmes, 1988). Jumlah pendapatan atau penjualan yang dihasilkan perusahaan dapat menunjukkan perputaran asset atau modal yang dimiliki oleh perusahaan sehingga semakin besar pendapatan atau penjualan yang diperoleh perusahaan semakin besar pula tingkat kompleksitas perusahaan dalam menggunakan informasi akuntansi.

Lama pembukaan usaha dapat mempengaruhi tingkat pendapatan, lama seorang pelaku bisnis menekuni bidang usahanya akan mempengaruhi produktivitasnya (kemampuan profesionalnya/ keahliannya), sehingga dapat menambah efisiensi dan mampu menekan biaya produksi lebih kecil daripada hasil penjualan. Semakin lama menekuni bidang usaha perdagangan akan semakin meningkatkan pengetahuan tentang selera ataupun perilaku konsumen (Wicaksono, 2011).

Beberapa penelitian yang ditelah dilakukan yang berkaitan dengan penelitian ini diantaranya Aufar (2013) menyatakan bahwa jenjang pendidikan berpengaruh terhadap pengguanaan informasi akuntansi sedangkan Wulandari (2016) menyimpulkan bahwa jenjang pendidikan dan skala usaha tidak berpengaruh

terhadap penggunaan informasi akuntansi, sedangkan lama usaha mempunyai pengaruh terhadap penggunaan informasi akuntansi. Hasil penelitian Yasa et al. (2017) dan Widiyanti

(2013) 
mengemukakan bahwa skala usaha mempunyai pengaruh signifikan terhadap penggunaan informasi akuntansi. Aufar (2013) menemukan bahwa jenjang pendidikan, ukuran usaha, lama usaha dan latar belakang pendidikan berpengaruh terhadap penggunaan informasi akuntansi. Sedangkan Berbeda dengan hasil penelitian Abang dan Encu (2009) dimana skala usaha berpengaruh negatif terhadap penggunan informasi akuntansi dan penelitian Hariyadi (2012) menemukan bahwa pendidikan pemilik usaha tidak berpengaruh terhadap penggunaan informasi akuntansi. Didin (2009) dimana lama usaha berpengaruh negatif terhadap penggunan informasi akuntansi.

Berdasarkan fenomena dan perbedaan hasil penelitian peneliti tertarik untuk melakukan penelitian "Pengaruh Jenjang Pendidikan, Skala Usaha dan Lama Usaha terhadap Penggunaan Informasi Akuntansi pada UMKM di Kecamatan Ciawigebang”.

\section{KERANGKA TEORITIS DAN PENGEMBANGAN HIPOTESIS}

Jenjang pendidikan adalah tahapan dasar yang ditetapkan berdasarkan tingkat perkembangan peserta didik, tujuan yang akan dicapai dan kemampuan yang dikembangkan (UU No. 20 Tahun 2003 Bab 1, Pasal 1, Ayat 8). Tingkat pendidikan berpengaruh terhadap perubahan sikap dan perilaku hidup sehat. Tingkat pendidikan yang lebih tinggi akan memudahkan sesorang atau masyarakat untuk menyerap informasi dan mengimplementasikannya dalam perilaku dan gaya hidup sehari-hari, khususnya dalam hal kesehatan. Pendidikan formal membentuk nilai bagi seseorang terutama dalam menerima hal baru (Suhardjo, 2007).

Informasi akuntansi akan memudakan perusahaan dalam mengelola laporan keuangannya. Aufar (2013) menyatakan bahwa jenjang pendidikan berpengaruh terhadap penggunaan informasi akuntansi. Jenjang pendidikan sangat berpengaruh terhadap pemahaman akuntansi disetiap pemilik UMKM yang nantinya akan berpengaru hterhadap persiapan dan kemampuan pemilik UMKM dalam penggunaan informasi akuntansi. Jenjang pendidikan yang rendah membuat pemilik UMKM kurang begitu memahami dalam penggunaan informasi akuntansi dibandingkan dengan pemilik UMKM yang memiliki jenjang pendidikan formal yang lebih tinggi.

Semakin tinggi jenjang pendidikan pelaku umkm maka semakin banyak informasi yang akan didapat sehingga penggunaa informasi akuntansi akan semakin baik. Hal ini sejalan dengan hasil penelitian Marwah (2012) dimana terdapat hubungan positif jenjang pendidikan dengan penggunaan informasi akuntansi.

$\mathrm{H}_{1}$ : Jenjang pendidikan berpengaruh positif terhadap penggunaan informasi akuntansi

Menurut Holmes dan Nicholls, (1988) dalam Grece (2003) skala usaha merupakan kemampuan perusahaan dalam mengelola usahanya dengan melihat total aset, berapa jumlah karyawan yang dipekerjakan dan berapa besar 
pendapatan yang diperoleh perusahaan dalam satu periode akuntansi. Jumlah pendapatan atau penjualan yang dihasilkan perusahaan dapat menunjukkan perputaran asset atau modal yang dimiliki oleh perusahaan sehingga semakin besar pendapatan atau penjualan yang diperoleh perusahaan semakin besar pula tingkat kompleksitas perusahaan dalam menggunakan informasi akuntansi. Jumlah pendapatan atau penjualan yang dihasilkan perusahaan dapat menunjukkan perputaran aset atau modal yang dimilikki oleh perusahaan, sehingga semakin besar pendapatan atau penjualan yang diperoleh perusahaan maka semakin besar pula tingkat kompleksitas perusahaan dalam menggunakan informasi akuntansi. Jumlah karyawan dapat menunjukkan berapa kapasitas perusahaan dalam mengoprasionalkan usahanya, semakin besar jumlah karyawan semakin besar tingkat kompleksitas perusahaan, sehingga informasi akuntansi sangat dibutuhkan (Arizali, 2013). Semakin baik pengelolaan skala usaha maka semakin baik pula penggunaan informasi akuntansinya. Hal ini sesuai dengan penelitian yang dilakukan oleh Samsidar dan Rojay (2013), Anas dan Lestari (2015) menunjukan bahwa skala usaha berpengaruh positif terhadap penggunaan informasi akuntansi.

$\mathrm{H}_{2}$ : Skala usaha berpengaruh positif terhadap penggunaan informasi akuntansi

Lama usaha merupakan lamanya pedagang berkarya pada usaha perdagangan yang sedang di jalani saat ini (Asmie, 2008). Semakin lama menekuni bidang usaha perdagangan akan makin meningkatkan pengetahuan tentang selera ataupun perilaku konsumen (Wicaksono, 2011).

Lama usaha suatu Usaha Mikro, Kecil dan Menegah (UMKM) berdiri atau umur dari UMKM semenjak usaha tersebut berdiri pada saat penulis melakukan penelitian ini (Murniati, 2002). Dengan Asumsi bahwa semakin lama usaha tersebut berjalan maka akan mengakibatkan adanya perkembangan usaha yang sangat signifikan kearah yang positif atau negatif. Perkembangan dari usaha tersebut tergantung dari iklim perdagangan dan persaingan yang terjadi didunia usaha atau pasar. Dan biasanya usaha yang lebih lama berdiri cenderung lebih berkembang karena sudah memiliki banyak pengalaman dalam menjalankan usahanya. Dan juga usaha yang memiliki umur yang bisa dibilang mapan lebih dapat bersaing dengan usaha/pelaku UMKM lainnya.

Holmes dan Nicholls (1988) memperlihatkan bahwa penyedia informasi akuntansi dipengaruhi oleh usia usaha. Hasil penelitian ini menyatakan bahwa perusahaan yang berdiri selama 11-20 tahun menyediakan lebih banyak informasi akuntansi, berbeda dengan perusahaan yang lebih tua usianya, bahwa semakin lama usia perusahaan terdapat kecenderungan untuk menyatakan penggunaan informasi akuntansi.

Lamanya seorang pelaku bisnis menekuni bidang usahanya akan mempengaruhi kemampuan profesionalnya. Semakin lama menekuni bidang usaha perdagangan 
akan makin meningkatkan pengetahuan tentang selera ataupun perilaku konsumen. Keterampilan berdagang makin bertambah dan semakin banyak pula relasi bisnis maupun pelanggan yang berhasil dijaring (Asmie, 2008).

Hal ini sesuai dengan penelitian yang dilakukan oleh Ramzi dan Rojay (2013) dimana lama usaha berpengaruh positif terhadap penggunan informasi akuntansi.

Senada dengan hasil penelitian yang dilakukan oleh Wahyudi (2009) dimana lama usaha berpengaruh positif terhadap penggunan informasi akuntansi. Andi dan Murni (2009) dimana dalam penelitannya menunjukan bahwa lama usaha bepengaruh positif terhadap penggunaan informasi akuntansi.

$\mathrm{H}_{3}$ : Lama usaha berpengaruh positif terhadap penggunaan informasi akuntansi

\section{METODOLOGI PENELITIAN}

Metode yang digunakan dalam penelitian ini menggunakan metode deskriptif dan verifikatif. data yang digunakan adalah data primer dari hasil wawancara dan kuisioner yang diberikan secara langsung kepada responden. Populasi yang digunakan dalam penelitian ini adalah seluruh usaha mikro, kecil dan menengah yang terdapat di Kecamatan Ciawigebang Kabupaten Kuningan sebanyak 380 UMKM. Dengan unit observasi adalah pemilik perusahaan kecil dan menengah yang terdapat di Kecamatan Ciawigebang. Teknik pengambilan sampel yang digunakan adalah Sampel proporsi atau Propotional sampel yang merupakan sebuah proses sampling yang memungkinkan peneliti ini dilakukan untuk menyempurnakan penggunaan teknik sampel berstrara atau sampel wilayah dengan taraf kesalahan yang dapat ditolerir adalah sebesar $10 \%$. untuk menentukan besarnya sampel dilakukan dengan menggunakan rumus slopin menurut Sugiyono (2014:86) yaitu :

$$
\mathrm{n}=\frac{N}{1+N e^{2}}
$$

Berdasarkan hasil perhitungan diatas peneliti mengambil jumlah responden yang akan dijadikan sampel dalam penelitian ini sebanyak 79 responden. Dalam penelitian ini yang menjadi variabel dependen atau variabel terikat yaitu penggunaan informasi akuntansi (Y). sedangkan variabal independen dalam penelitian ini yang menjadi variabel independensi atau variabel bebasnya yaitu Jenjang pendidikan, skala usaha dan lama usaha.

\section{HASIL DAN PEMBAHASAN}

Objek dalam penelitian ini adalah pelaku usaha mikro kecil dan menengah di kecamatan Ciawigebang. Variabel independen dalam penelitian ini adalah jenjang pendidikan, skala usaha dan lama usaha. Variabel dependen dalam penelitian ini adalah penggunaan informasi akuntansi. Penelitian ini dilakukan pada tahun 2018 dan responden dalam penelitian ini adalah pemilik umkm di kecamatan Ciawigebang. Jumlah responden yaitu 79 responden.

\section{ANALISIS DATA \\ Hasil Pengujian Validitas dan Reliabilitas}


Berdasarkan hasil pengujian validitas yang dilakukan terhadap instrumen pernyataan kuesioner dari masing-masing variabel dapat diperoleh hasil bahwa jenjang pendidikan, skala usaha dan lama usaha adalah valid. Sedangkan berdasarkan pengujian reliablitas setiap variabel memiliki tingkat keandalan tinggi karena $r$ lebih besar dari 0,6 sehingga dapat disimpulkan bahwa masing-masing variabel memenuhi kreteria reliabel.

\section{Uji Asumsi Klasik}

Hasil pengujian normalitas dengan uji Kolmogorov-Smirnov dapat diketahui bahwa nilai Asymp. Sig. (2-tailed) nya untuk variabel Jenjang Pendidikan sebesar 0,171, Skala usaha sebesar 0,253 lama usaha sebesar 0,170 dan variabel kinerja sebesar 0,135 karena semua variabel > 0,05 , maka dapat disimpulkan bahwa data pada penelitian ini berdistribusi normal.

Hasil uji heteroskedastisitas dengan menggunakan gambar

Tabel 1 Hasil Regresi Berganda

\begin{tabular}{lccc}
\hline \multicolumn{1}{c}{ Variabel } & Koefisien Regresi & $\mathrm{t}_{\text {hitung }}$ & Sig. \\
\hline konstan & 11,810 & 4,140 & 0,000 \\
Jenjang pendidikan & 0,192 & 2,595 & 0,005 \\
Skala usaha & 0,326 & 2,766 & 0,007 \\
Lama usaha & 0,445 & 2,161 & 0,004 \\
\hline
\end{tabular}

Adjusted R Square 0,343

Sumber: data sekunder diolah dari SPSS

Berdasarkan tabel di atas, hasil regresi berganda dapat dibuat persamaan sebagai berikut:

$$
\begin{aligned}
\mathrm{Y}= & 11,810+0,192 \mathrm{JP}+0,326 \mathrm{SU}+ \\
& 0,445 \mathrm{LU}
\end{aligned}
$$

scatterplot, dapat diketahui bahwa titik-titik menyebar dan tidak membentuk pola. Sehingga dapat disimpulkan bahwa data dalam penelitian ini tidak terjadi heteroskedastisitas.

Hasil uji multikolinieritas dengan menggunakan uji Variance Inflation Factor (VIF) menunjukkan untuk setiap variabel yang diuji memiliki nilai < 10. Dengan demikian, dapat disimpulkan bahwa dalam penelitian ini tidak terjadi gejala multikolinieritas.

Hasil uji autokorelasi dengan uji Durbin Watson diperoleh nilai dl $1,279<1,374<1,427$ du. Dengan demikian dapat disimpulkan bahwa tidak terjadi gejala autokorelasi dalam persamaan regresi.

Berdasarkan analisis regresi berganda dengan bantuan software SPSS 20.0 for Windows, diperoleh hasil perhitungan yang dapat dijabarkan dalam tabel berikut ini:$$
\text { , }
$$

Berdasarkan hasil pengujian hipotesis pertama diperoleh nilai $\mathrm{t}$ hitung $>\mathrm{t}$ tabel 2,595 >1,664 dengan nilai sig. $0,005<$ nilai $\alpha 0,05$. Sehingga Ho ditolak dan $\mathrm{H}_{\mathrm{a}}$ diterima. Dan arah koefisien positif. Dengan demikian dapat simpulkan bahwa Jenjang Pendidikan berpengaruh 
positif signifikan terhadap Penggunaan informasi akuntansi.

Berdasarkan hasil pengujian hipotesis kedua diperoleh nilai $t$ hitung $>\mathrm{t}$ tabel 2,766 >1,664 dengan nilai sig. $0,007<$ nilai $\alpha 0,05$. Sehingga Ho ditolak dan $\mathrm{H}_{\mathrm{a}}$ diterima. Dan arah koefisien positif. Dengan demikian dapat simpulkan bahwa skala usaha berpengaruh positif signifikan terhadap Penggunaan informasi akuntansi.

Berdasarkan hasil pengujian hipotesis kedua diperoleh nilai $t$ hitung $>\mathrm{t}$ tabel 2,161>1,664 dengan nilai sig. $0,004<$ nilai $\alpha 0,05$. Sehingga Ho ditolak dan $\mathrm{H}_{\mathrm{a}}$ diterima. Dan arah koefisien positif. Dengan demikian dapat simpulkan bahwa lama usaha berpengaruh positif signifikan terhadap Penggunaan informasi akuntansi.

Berdasarkan hasil pengujian determinasi diperoleh nilai Adjusted $R$ Square adalah 0,343. Artinya sebesar 34,3 persen variasi perubahan variabel penggunaan informasi akuntansi dapat dijelaskan oleh variasi perubahan variabel jenjang pendidikan, skala usaha dan lama usaha sedangkan 55,7\% dapat dijelaskan oleh variabel lain yang tidak teliti.

\section{PEMBAHASAN}

Pengaruh Jenjang Pendidikan terhadap Penggunaan Informasi Akuntansi

Berdasarkan hasil pengujian hipotesis pertama, diperoleh kesimpulan bahwa Jenjang Pendidikan berpengaruh positif signifikan terhadap penggunaan informasi akuntansi. Hal ini berarti bahwa semakin tinggi jenjang pendidikan pemilik UMKM maka semakin baik dalam menggunakan informasi akuntansi. Karena dengan jenjang pendidikan yang tinggi seorang pemilik UMKM akan lebih memahami mengenai informasi akuntansi sehingga memudakan perusahaan dalam mengelola laporan keuangannya. Jenjang pendidikan mempunyai pengaruh yang besar dalam keberhasilan suatu UMKM dimana pemilik UMKM harus mempunyai daya kritis yang kuat terhadap perkembangan teknologi dan informasi sehingga UMKM yang menggunakan informasi akuntansi dengan baik akan dapat mengevaluasi pencapaian hasil usahanya dengan menganalisis laporan keuangan.

Hasil penelitian ini sesuai dengan hasil penelitian yang dilakukan oleh Aufar (2013) mengemukakan bahwa jenjang pendidikan berpengaruh positif signifikan terhadap penggunaan informasi akuntansi.

\section{Pengaruh Skala Usaha Terhadap Penggunaan Informasi Akuntansi}

Berdasarkan hasil pengujian hipotesis kedua, diperoleh kesimpulan bahwa skala usaha berpengaruh positif signifikan terhadap penggunaan informasi akuntansi. Hal ini berarti bahwa semakin besar skala usaha maka semakin banyak informasi akuntansi yang dibutuhkan untuk kepentingan usaha. Informasi akuntansi sangatlah dibutuhkan oleh pelaku UMKM karena menghasilkan informasi yang dapat membantu pemilik UMKM dalam mengambil keputusan.

Hal ini sesuai dengan penelitian yang dilakukan oleh Yasa et al. (2017) dimana skala usaha 
berpengaruh positif terhadap penggunan informasi akuntansi.

\section{Pengaruh Lama Usaha Terhadap Penggunaan Informasi Akuntansi}

Berdasarkan hasil pengujian hipotesis ketiga, diperoleh kesimpulan bahwa lama usaha berpengaruh positif signifikan terhadap penggunaan informasi akuntansi. Hal ini berarti bahwa semakin lama usia usaha yang dijalankan maka semakin penting informasi akuntansi yang dibutihkan oleh pelaku bisnis. Semakin lama menekuni bidang usaha akan semakin besar usahanya sehingga pelaku bisnis akan memanfaatkan informasi akuntansi untuk mendukung aktivitas bisnisnya.

Hal ini sesuai dengan penelitian yang dilakukan oleh Aufar (2013) dan Wulandari (2016) dimana lama usaha berpengaruh positif terhadap penggunan informasi akuntansi.

\section{KESIMPULAN}

Berdasarkan hasil penelitian dan pembahasan, maka kesimpulan yang dapat diambil dari penelitian ini yaitu jenjang pendidikan, skala usaha dan lama usaha berpengaruh positif terhadap penggunaan informasi akuntansi. Hal ini berarti bahwa penggunaan informasi akuntansi pada UMKM dapat ditentukan oleh faktor-faktor seperti jenjang pendidikan, skala usaha dan lama usaha.

Keterbatasan dalam penelitian ini berkaitan dengan lingkup penelitian yang hanya di wilayah kecamatan Ciawigebang. Oleh karena itu, untuk penelitian selanjutnya dapat memperluas sampel penelitian dengan mengambil sampel di wilayah kabupaten yang cakupan nya lebih luas.

\section{DAFTAR PUSTAKA}

Aufar, A. 2013. Faktor-Faktor Yang Mempengaruhi Penggunaan Informasi Akuntansi Pada UMKM (Usaha Kecil dan Menengah). Jurnal Ilmiah, Universitas Widyatama.

Badan perindustrian koperasi dan UMKM. 2013. Data base UMKM per sektor usaha Kabupaten Sragen. Sragen

Depdiknas. 2003. UU Nomor 20 tahun 2003 tentang Sisdiknas. Jakarta

Dewan Standar Akuntansi Keuangan. 2009. Standar akuntansi keuangan entitas tanpa akuntabilitas publik. Ikatan Akuntan Indonesia : Jakarta

Fitriyah, H. (2006). Analisis faktorfaktor yang mempengaruhi penggunaan informasi akuntansi pada usaha kecil dan menengah kabupaten Sidoharjo.Tesis Universitas Airlangga Surabaya

Fuad, S. 2013. Faktor-faktor yang mempengaruhi penggunaan informasi akuntansi pada usaha kecil dan menengah (Study pada Kab. Sido Rukun Semarang. Diponegoro Journal of accounting Vol.2 No.3 
Grace, T. S. 2003. Analisis FaktorFaktor yang Mempengaruhi Penyiapan dan Penggunaan Informasi Akuntansi Pada Perusahaan Kecil dan Menengah di Jawa Tengah. Tesis, Universitas Diponegoro.

Hariyadi. 2012. Faktor-Faktor Yang Mempengaruhi Penggunaan Informasi Akuntansi Pada Usaha Mikro Dan Menengah (UMKM) Yang Bergerak Dibidang Jenis Usaha Makanan Di Kota Tanjung Pinang. Fakultas Ekonomi UMRAH

Handayani, B.S. 2011. Faktor yang mempengaruhi penggunaan informasi akuntansi pada usaha kecil dan menengah, Vol. II, No.I, ISSN 1412-0240

Holmes, Scott And Nicholls. 1988. An Analysis Of The Use Of Accounting Informationby Australian Small Business. Journal of small business management, 26(20). 57-68

Ikatan Akuntan Indonesia. 1999. Standar akuntansi keuangan. Jakarta: Salemba Empat

Murniati. 2002. Analisis FaktorFaktor yang Mempengaruhi Penyiapan dan Penggunaan Informasi Akuntansi Pada Pengusaha Kecil dan Menengah di Jawa Tengah. Tesis, Universitas Diponegoro
Romney. 2012. Sistem Informasi Akuntansi. Jakarta: Bumi Aksara

Setiyadi. 2009. Pengaruh pengetahan akuntansi terhadap kualitas laporan keuangan. Jurnal skripsi. Jakarta

Suhairi. 2004. Pengaruh sistem informasi akuntansi terhadap kualitas laporan keuangan. Jurnal skripsi. Jakarta

Sugiyono. 2014. Metode Penelitian Kuantitatif dan Kualitatif dan $R \& D$. Bandung: Alfabeta CV.

Suhardjo, 2007. Pendidikan formal. Yogyakarta Penerbit Liberty.

Undang-Undang Republik Indonesia Tentang UMKM No 9 Tahun1998

Wahyudi, Muhammad. 2009. Analisis Faktor-Faktor Yang Mempengaruhi Penggunaan Informasi Akuntansi Pada Usaha Kecil dan Menengah (UKM) Di Yogyakarta. Tesis, Universitas Diponegoro

Widiyanti, M. 2013. Analisis FaktorFaktor Yang Mempengaruhi Persepsi Pengusaha Kecil dan Menengah atas Penggunaan Informasi Akuntansi. Skripsi, Universitas Negeri Semarang

Wulandari, A. D. V. 2016. Pengaruh Jenjang Pendidikan, Lama Usaha, Skala Usaha dan Pengetahuan Akuntansi terhadap Penggunaan Informasi Akuntansi Pada UMKM Mebel Di Kabupaten Sragen. Skripsi. Jurusan 
Akuntansi Syariah, Insitut Agama Islam Negeri Surakarta.

Yasa, K. S. H., Herawati, N. T., dan Ni Luh G. E. S. 2017. Pengaruh Skala Usaha, Umur Usaha, Pengetahuan dan Akuntansi terhadap Penggunaan Informasi
Akuntansi Pada Usaha Kecil dan Menengah (UKM) di Kecamatan Buleleng Dengan Ketidakpastian Lingkungan Sebagai Variabel Pemoderasi. E-Journal Universitas Akuntansi, Ganesha. 